\title{
Assessment of De-Radicalization Hypothesis in Sub-Saharan Africa
}

\author{
Ishmael D. Norman ${ }^{1}$
}

This study considers de-radicalization hypothesis in relation to the youth of Sub-Saharan Africa and the purported re-training from engagement in violent extremism. The hypothesis assumes a waning or reduction in youth radicalism in Sub-Saharan Africa. This change is reported to be due to the reduced opportunities for recruitment into violent extremist groups, through proselytization in the virtual or real world. The instigators are Muslim Clerics, or Jihadist agents, or even through 'Self-radicalization'. The reduced effect is, apparently, attributed to the successes garnered by the international war on terror. For proof of concept of youth radicalism, and therefore, deradicalism, a review of the reported motivations of the youth to jihadist causes was conducted. This was to assess if those motivations are still prevalent in the case of Sub-Saharan Africa's. If so, can the argument be sustained that, once there was active radicalism and now, there is de-radicalism? The evidence on de-radicalization of the youth even in Europe and in Sub-Saharan Africa as reported by observers and security organizations in Sub-Saharan Africa and else, is not compatible with the quantum of the youth from Sub-Saharan Africa believed to have been radicalized. Among other weaknesses it fails to establish a baseline, and, thereafter, the percentage of change of those de-radicalized. [Article copies available for a fee from The Transformative Studies Institute. E-mail address: journal@transformativestudies.org Website: http://www.transformativestudies.org (02019 by The Transformative Studies Institute. All rights reserved.]

KEYWORDS: Youth de-radicalization; Terrorism; War on Terror; Islamic Proselytization; Sub-Saharan Africa.

\footnotetext{
${ }^{1}$ Ishmael Norman obtained a BA in 1982 from VT, JD in 1985 from the Franklin Pierce Law Center, NH, USA. In 2008, he obtained a Ph. D in Public Health, University of Ghana; lectured at the School of Public Health, University of Ghana; was the HOD and the Director: Strengthening Leadership for Disaster Resilience Program, Africa, based at both UG, Legon/UHAS, Ho, VR. He was also the PI for a USAID funded program: Resilient Africa for the West African Sub-region. He is currently employed at the University of Health and Allied Sciences.
} 